\title{
GSK126 (EZH2 inhibitor) interferes with ultraviolet A radiation-induced photoaging of human skin fibroblast cells
}

\author{
HAIYAN QIN, GUANG ZHANG and LIANBO ZHANG
}

Department of Plastic Surgery, China-Japan Union Hospital of Jilin University, Changchun, Jilin 130033, P.R. China

Received May 17, 2016; Accepted March 24, 2017

DOI: $10.3892 /$ etm.2018.5863

\begin{abstract}
Polycomb group genes (PcG) encode chromatin modification proteins that are involved in the epigenetic regulation of cell differentiation, proliferation and the aging processes. The key subunit of the PcG complex, enhancer of zeste 2 polycomb repressive complex 2 subunit (EZH2), has a central role in a variety of mechanisms, such as the formation of chromatin structure, gene expression regulation and DNA damage. In the present study, ultraviolet A (UVA) was used to radiate human dermal fibroblasts in order to construct a photo-aged cell model. Subsequently, the cell viability assay, Hoechst staining, apoptosis detection using flow cytometry, senescence-associated $\beta$-galactosidase (SA- $\beta$-gal) staining and erythrocyte exclusion experiments were performed. GSK126, a histone methylation enzyme inhibitor of EZH2, was used as an experimental factor. Results suggested that GSK126 downregulated the mRNA expression levels of EZH2 and upregulated the mRNA expression levels of BMI-1. Notably, GSK126 affected the transcription of various photoaging-related genes and thus protected against photoaging induced by UVA radiation.
\end{abstract}

\section{Introduction}

Aging is one of the most basic natural laws in the biological world. Skin aging is an important indicator of human aging that results from a combination of internal and external environmental factors (1). Aging caused by internal factors is called natural aging. Notably, the exogenous environment may also contribute to human skin aging. Skin aging may also be caused by ultraviolet (UV) radiation, which is called photoaging (2). Furthermore, ultraviolet A (UVA) is the ultraviolet light with the longest wavelength that can reach the dermal layer of the skin and is a major contributor of photoaging (3).

Correspondence to: Dr Lianbo Zhang, Department of Plastic Surgery, China-Japan Union Hospital of Jilin University, 126 Xiantai Street, Changchun, Jilin 130033, P.R. China

E-mail: doctorzhanglianbo@163.com

Key words: photoaging, polycomb group genes, ultraviolet A, human skin fibroblast, enhancer of zeste 2 polycomb repressive complex 2 subunit
Typical characteristics of photoaging include deep and rough wrinkles, pigmentation spots, dry and loose skin atrophy, telangiectasia, photoaging purpura and precancerous lesions (4). Notably, photoaging may result in more severe outcomes than natural aging; for example, long-term ultraviolet radiation may trigger skin cancer (5). In general, molecular changes in photoaging are thought to be an enhancement and amplification of molecular changes associated with age-related skin aging (6).

Dermal fibroblasts are crucial cellular components involved in the structural integrity of the skin (7). They serve as the primary producer of the extracellular matrix scaffold within the dermis, including collagen, elastin and glycosaminoglycans (8). Studies have indicated that UV exposure from the sun causes apoptosis of dermal fibroblasts (photodamage) and contributes to the development of photoaging (9). Hyaluronic acid (HA), an extracellular matrix molecule synthesized by hyaluronic acid synthase enzymes (HAS), serves a role in regulating apoptosis in fibroblasts (10). Injection of HA fillers provides enrichment of one of the primary ECM compounds, deep hydration of the skin and strongly stimulates fibroblasts, which act on specific receptors cluster of differentiation (CD)44, HA-mediated cell motility and intercellular adhesion molecule-1 to synthesize novel scaffold compounds $(11,12)$.

UV has been demonstrated to activate the MAPK signaling pathway and increase the expression of matrix metalloproteinases (MMPs), which promote degradation of collagen (13). Large-scale decomposition of collagen is the basis of photoaging $(14,15)$.

UV light is absorbed by the skin molecules, and may produce a large number of harmful compounds, including hydrogen peroxide and superoxide anions, which are called reactive oxygen species (ROS). These promote oxidative damage to cell components, including cell walls, lipid membranes, mitochondria and DNA, and promote apoptosis, cellular aging and inflammation (2). ROS may also influence the photoaging process indirectly by affecting MAPK and transforming growth factor- $\beta$ signaling (9). The mechanism of photoaging is complex and various regulatory signaling pathways have been associated with this process.

Polycomb group genes (PcG) encode chromatin modification proteins that control development and have key roles in the regulation mechanisms of cell proliferation, differentiation, aging and tumorigenesis (16). Because PcG relies on multiple protein complexes, it is called multiple comb inhibition 
complexes (PRCs). Polycomb repressive complex (PRC)1 and PRC2 are the active components of PcG (17).

In the PcG gene family, the subunit E(z) or EZH2 of the PRC2 complex serves a central role in gene regulation (18). $\mathrm{EZH} 2$ is involved in the formation of the chromatin structure, regulation of gene expression and growth control, and thus has pluripotency (19). Previous studies have indicated that the appearance of senescence-associated heterochromatic foci is associated with the increase of $\mathrm{H} 3 \mathrm{~K} 9$ methylation level in aging human fibroblasts (20).

The PRC1 complex subunit BMI-1 is a negative regulator of the inhibitor of CDK4/alternative reading frame (Ink4a/Arf) locus, which encodes cell cycle regulatory proteins and tumor suppressors, including P16Ink4a and P19Arf (21). However, little research exists on PcG epigenetic regulation in the photoaging process in human skin. Therefore, the present study aimed to investigate whether EZH2 and BMI-1 are involved in the regulation of UVA radiation-induced photoaging in human skin fibroblasts (HSFs). The effects of inhibitors on UVA radiation-induced photoaging in fibroblasts was investigated using the EZH2 inhibitor, GSK126. The results of the present study may provide a novel theoretical basis for the research and treatment of skin photoaging.

\section{Materials and methods}

Cell culture. HSFs were purchased from CoBioer Biosciences Co., Ltd. (Nanjing, China). The cells were cultured in Dulbecco's modified Eagle medium (DMEM) (Gibco; Thermo Fisher Scientific, Inc., Waltham, MA, USA) supplemented with $10 \%$ fetal bovine serum (ScienCell Research Laboratories, Inc., Carlsbad, CA USA), $1 \%$ penicillin and $1 \%$ streptomycin. The cells were incubated under $5 \% \mathrm{CO}_{2}$ at $37^{\circ} \mathrm{C}$.

Chemicals. GSK126 was purchased from Selleck Chemicals Scientific, Inc., Houston, TX, USA and dissolved in dimethyl sulfoxide. GSK 126 was stored at $-20^{\circ} \mathrm{C}$ in a freezer and diluted with medium to a final concentration $(2 \mu \mathrm{M})$ for experiments.

HSFs $\left(1 \times 10^{5}\right.$ cells/well) were seeded in 6-well plates with DMEM supplemented with $10 \%$ fetal bovine serum, $1 \%$ penicillin and $1 \%$ streptomycin. Cells were incubated in an atmosphere containing $5 \% \mathrm{CO}_{2}$ at $37^{\circ} \mathrm{C}$ for $24 \mathrm{~h}$. The medium was replaced with different concentrations $(0,2,4$ and $8 \mu \mathrm{M})$ of GSK126. Once the cells were further incubated for $24 \mathrm{~h}$ at $37^{\circ} \mathrm{C}$, the cells were collected for RNA extraction and further experiments.

HSFs $\left(1 \times 10^{5}\right.$ cells/well) were seeded in 6-well with DMEM containing $10 \%$ fetal bovine serum, $1 \%$ penicillin and $1 \%$ streptomycin. The cells were incubated in an atmosphere containing $5 \% \mathrm{CO}_{2}$ at $37^{\circ} \mathrm{C}$ for $24 \mathrm{~h}$. Cells were divided into four groups: (-), cells without UVA and GSK126; GSK126 $(2 \mu \mathrm{M})$; UVA $\left(10 \mathrm{~J} / \mathrm{cm}^{2}\right)$; and UVA $\left(10 \mathrm{~J} / \mathrm{cm}^{2}\right)+$ GSK126 $(2 \mu \mathrm{M})$. The cell culture medium was replaced with an equal volume of sterile phosphate-buffered saline (PBS) in all groups (prior to radiation exposure in the irradiated groups). The radiation dose used was $10 \mathrm{~J} / \mathrm{cm}^{2}$ in the UVA $\left(10 \mathrm{~J} / \mathrm{cm}^{2}\right)$ and UVA $\left(10 \mathrm{~J} / \mathrm{cm}^{2}\right)+\mathrm{GSK} 126$ $(2 \mu \mathrm{M})$ groups. The PBS was discarded at the end of UVA irradiation, media containing serum and antibiotics were added to the (-) and UVA $\left(10 \mathrm{~J} / \mathrm{cm}^{2}\right)+\mathrm{GSK} 126(2 \mu \mathrm{M})$ groups, media containing serum and antibiotics and $2 \mu \mathrm{M}$ GSK126 was added to GSK126 $(2 \mu \mathrm{M})$ and UVA $\left(10 \mathrm{~J} / \mathrm{cm}^{2}\right)+\mathrm{GSK} 126$ $(2 \mu \mathrm{M})$ groups, and cells were further incubated at $37^{\circ} \mathrm{C}$ for $24 \mathrm{~h}$. Images of the cells were then captured with an optical microscope (magnification, $\mathrm{x} 40$ ) to observe the cell growth and collected for RNA extraction and further experiments.

UVA irradiation. The ZF-1 Three Ultraviolet analyzer (Shanghai HQ Instruments Co., Ltd., Shanghai, China) was used as a radiation source, the wavelength was set to $365 \mathrm{~nm}$ and an UV radiation meter (Kühnast Strahlungstechnik, Dresden, Germany) was used to measure the radiation dose. According to the experiment, the appropriate number of HSFs were inoculated onto the corresponding orifice plates and, $24 \mathrm{~h}$ later, the desired radiation dose $\left(\mathrm{J} / \mathrm{cm}^{2}\right)$ was selected for UV irradiation. The cell culture medium was replaced with an equal volume of sterile PBS prior to radiation exposure. The cells were placed under the UV analyzer for irradiation under sterile conditions and the irradiation height was $<2 \mathrm{~cm}$. Following irradiation, PBS was replaced with fresh medium.

Cell viability assay. A cell counting kit-8 (CCK-8; Dojindo Molecular Technologies, Inc., Kumamoto, Japan) assay was used to determine cell viability, according to the manufacturer's instructions. It is based on dehydrogenase activity detection in viable cells. The formazan dye generated by dehydrogenases absorbs light at a wavelength of $450 \mathrm{~nm}$. The amount of formazan dye in cells is directly proportional to the number of living cells.

HSFs were seeded into 96-well plates at a density of $0.5 \times 10^{4}$ cells/well, with $200 \mu 1$ of culture medium per well in triplicate wells for each experimental group. When cells were adherent ( $24 \mathrm{~h}$ post seeding), they were divided into four different UVA treatment groups: $0,2.5,5$ and $10 \mathrm{~J} / \mathrm{cm}^{2}$. At specific time points after irradiation ( 0,12 and $24 \mathrm{~h}), 20 \mu \mathrm{l}$ of CCK-8 reagent was added to each well. After incubation for 1,2 , or $3 \mathrm{~h}$ at $37^{\circ} \mathrm{C}$, absorbance was detected at $450 \mathrm{~nm}$.

Hoechst staining. A Hoechst apoptosis staining kit (Beyotime Institute of Biotechnology, Haimen, China) was used to determine cellular apoptosis, according to the manufacturer's instructions. Under this staining, apoptotic nuclei demonstrate a dense white staining with fragmentation. Briefly, sterile cover slips were placed at the bottom of 6-well plates, and $0.3 \times 10^{5}$ cells in $2 \mathrm{ml}$ of DMEM supplemented with $10 \%$ fetal bovine serum, $1 \%$ penicillin and $1 \%$ streptomycin were added to each well. A total of $24 \mathrm{~h}$ after cell irradiation, the medium was removed and $0.5 \mathrm{ml}$ of fixative solution was added. Cells were fixed for $10 \mathrm{~min}$ at room temperature. The cells were then washed twice with PBS for 3 min each time and $0.5 \mathrm{ml}$ Hoechst 33258 staining solution was added. The cells were stained in a shaker for $5 \mathrm{~min}$ at room temperature and subsequently washed twice with PBS for 3 min each time. The cells were then carefully mounted onto a glass slide with a drop of fluorescence quenching mounting liquid. The cells were then observed under a fluorescence microscope.

Apoptosis detection by flow cytometry. A total of $1.0 \times 10^{5}$ HSFs in $2 \mathrm{ml}$ of DMEM supplemented with $10 \%$ fetal bovine serum, $1 \%$ penicillin and $1 \%$ streptomycin were added to each 
well of 6-well plates in triplicate wells for each experimental group. When cells were adherent for $24 \mathrm{~h}$, they were exposed to different doses of irradiation $\left(0,2.5,5\right.$ and $\left.10 \mathrm{~J} / \mathrm{cm}^{2}\right)$. HSFs were transferred into 5-ml tubes and washed with PBS. An annexin V-FITC/PI apoptosis detection kit (Nanjing KGI Biological Technology Development Co., Ltd., Nanjing, China) was used to stain the nucleus according to the maunfacturer's instructions and the cells were resuspended in binding buffer $(100 \mu \mathrm{l})$. Subsequently, cells were filtered into tubes through filter paper to remove cell clumps. Following this, $50 \mu \mathrm{l}$ Annexin V-fluorescein isothiocyanate solution and $50 \mu \mathrm{l}$ propidium iodide were added to each tube. The tubes containing the cells were then incubated in the dark at room temperature for $15 \mathrm{~min}$. The cells were then analyzed by BD FACS Aria II SORP sorting flow cytometer (BD Biosciences, Franklin lake, NJ, USA). The excitation and emission wavelengths were 488 and $530 \mathrm{~nm}$, respectively.

Senescence-associated $\beta$-galactosidase (SA- $\beta$-gal) staining . SA- $\beta$-gal activity was determined $24 \mathrm{~h}$ after UVA irradiation. A Senescence $\beta$-Galactosidase Staining Kit was performed, according to the manufacturer's instructions (Beyotime Institute of Biotechnology). A total of $0.3 \times 10^{5}$ cells in $2 \mathrm{ml}$ of culture medium were added to each well of 6 -well plates in triplicate for each experimental group. A total of $24 \mathrm{~h}$ after cell irradiation, cells were washed once with PBS at room temperature, and $1 \mathrm{ml} \beta$-gal staining fixative solution was added to each well. The cells were fixed for $15 \mathrm{~min}$ at room temperature. The fixative solution was discarded and the cells were washed three times with PBS, 3 min for each wash. Staining fluid (1 ml) was subsequently added to each well. A plastic wrap was used to seal the 6-well plates and cells were incubated overnight at $37^{\circ} \mathrm{C}$. The following day, the cells were observed under an optical microscope.

Erythrocyte exclusion experiment (a particle exclusion assay). Human peripheral blood $(6 \mathrm{ml})$ was collected and the plasma and leukocyte layer were separated following centrifugation at $566 \mathrm{x} \mathrm{g}$ at $4^{\circ} \mathrm{C}$ for $5 \mathrm{~min}$. Following this, erythrocytes were washed three times with PBS, 3 min for each wash at $4^{\circ} \mathrm{C}$. The erythrocytes were fixed with $10 \%$ formaldehyde solution (5:1; Nanjing KeyGen Biotech Co., Ltd., Nanjing, China) for $10 \mathrm{~min}$ at room temperature, then erythrocytes were washed three times with PBS, 3 min for each wash at $4^{\circ} \mathrm{C}$ and diluted to an erythrocyte suspension at a final concentration of $10^{7}$ cells $/ \mathrm{ml}$. Cells were seeded in 6 -well plates at $0.5 \times 10^{4}$ cells/well. Once the cells were irradiated for $24 \mathrm{~h}, 100 \mu \mathrm{l}$ eythrocyte suspension was added to each well and the samples were incubated in an upright position for $5 \mathrm{~min}$ at $37^{\circ} \mathrm{C}$. Fibroblasts were observed using a particle exclusion assay and images were captured using a Zeiss Axiovert phase-contrast microscope (22). Hyaluronidase (200 $\mu \mathrm{l} ; 1 \mathrm{mg} / \mathrm{ml}$; Sigma-Aldrich; Merck KGaA, Darmstadt, Germany) was added to the $0 \mathrm{~J} / \mathrm{cm}^{2}$ dose group, mixed gently, and incubated for $5 \mathrm{~min}$ at $37^{\circ} \mathrm{C}$ before fibroblasts were observed under a microscope and images were captured.

Reverse transcription-quantitative polymerase chain reaction $(R T-q P C R)$. Total RNA was isolated from HSFs using TRIzol (Invitrogen; Thermo Fisher Scientific, Inc.), according to the manufacturer's instructions, and quantified spectrophotometrically. Total RNA (1 $\mu \mathrm{g})$ from each sample was subjected to first-strand cDNA synthesis using a PrimeScript ${ }^{\mathrm{TM}} \mathrm{RT}$ reagent kit with gDNA Eraser (Takara Biotechnology Co., Ltd., Dalian, China), according to the kit's instructions. cDNA was generated after the removal of genomic DNA by treatment at $42^{\circ} \mathrm{C}$ for $2 \mathrm{~min}$ and subjected to the following thermocycling conditions: $37^{\circ} \mathrm{C}$ for $15 \mathrm{~min}, 85^{\circ} \mathrm{C}$ for $5 \mathrm{sec}$; and maintenance at $4^{\circ} \mathrm{C}$.

A Takara PCR amplification kit (Takara Biotechnology Co., Ltd.) was used according to the manufacturer's protocol with a CFX Real-Time PCR Detection system (Bio-Rad Laboratories, Inc.) for qPCR. The fluorescent dye used was SYBR Green (Takara PCR amplification kit; Takara Biotechnology Co., Ltd.). The reaction conditions were as follows: Initial denaturation at $95^{\circ} \mathrm{C}$ for $3 \mathrm{~min}$; and 45 cycles of denaturation at $95^{\circ} \mathrm{C}$ for $15 \mathrm{sec}$, annealing at $54^{\circ} \mathrm{C}$ for $20 \mathrm{sec}$ and extension at $72^{\circ} \mathrm{C}$ for $30 \mathrm{sec}$. The primers used are demonstrated in Table I. Gene expression was normalized to the level of GAPDH in a given sample. The expression level of genes and gene alternative splicing products were calculated and analyzed using the $2^{-\Delta \Delta \mathrm{Cq}}$ relative quantification method (23). Each experimental treatment was conducted in triplicate.

Statistical analysis. All data are presented as mean \pm standard deviation. Data was analyzed using SPSS software (version 22.0; IBM Corp., Armonk, NY, USA). Analysis of variance followed by Dunnett's test was performed. $\mathrm{P}<0.05$ was considered to indicate a statistically significant difference.

\section{Results}

UVA radiation reduces fibroblast proliferation. As demonstrated in Fig. 1, the fibroblast proliferation activity in the $2.5,5$ and $10 \mathrm{~J} / \mathrm{cm}^{2}$ dose groups decreased gradually with the increase of UVA radiation dose. The $10 \mathrm{~J} / \mathrm{cm}^{2} \mathrm{UVA}$ radiation dose had the greatest effect on cell viability, indicating that $10 \mathrm{~J} / \mathrm{cm}^{2}$ of UVA radiation is able to markedly inhibit fibroblast proliferation (Fig. 1).

UVA radiation promotes fibroblast apoptosis. Hoechst staining revealed that cells treated with UVA radiation demonstrated apoptotic nuclei, with a dense white dye or crushed nuclei shape (Fig. 2A). Statistical analysis demonstrated that all doses of UVA radiation $\left(2.5,5\right.$ and $\left.10 \mathrm{~J} / \mathrm{cm}^{2}\right)$ significantly promoted fibroblast apoptosis $(\mathrm{P}<0.05)$ compared with the control group $\left(0 \mathrm{~J} / \mathrm{cm}^{2}\right)$ in a dose-dependent manner. The $10 \mathrm{~J} / \mathrm{cm}^{2}$ dose promoted fibroblast apoptosis with the most significant effect $\left(\mathrm{P}<0.01\right.$; Fig. 2B). The $10 \mathrm{~J} / \mathrm{cm}^{2}$ UVA radiation dose demonstrated the most marked promotion of fibroblast apoptosis compared with the control group (Fig. 2C and D). The detection of apoptosis by flow cytometry demonstrated that the number of all UVA radiation groups significantly increased compared to the control group $(\mathrm{P}<0.05$; Fig. $2 \mathrm{E})$.

UVA radiation induces fibroblast senescence. As demonstrated in Fig. 3A, the blue precipitate indicated $\beta$-gal activity and the presence of senescent cells. UVA radiation induced changes in HSF cellular senescence. The 5 and $10 \mathrm{~J} / \mathrm{cm}^{2}$ dose radiation groups significantly induced cellular senescence compared with the control group $(\mathrm{P}<0.05)$. The $10 \mathrm{~J} / \mathrm{cm}^{2}$ dose had the most significant effect on cellular senescence, whereas the 
Table I. Primers and conditions for polymerase chain reaction analysis.

\begin{tabular}{|c|c|c|}
\hline Gene & Direction & Primer sequences \\
\hline \multirow[t]{2}{*}{ EZH2 } & Forward & 5'-ATGCGACTGAGACAGCTCAA-3' \\
\hline & Reverse & 5'-TGGGATGACTTGTGTTGGAA-3' \\
\hline \multirow[t]{2}{*}{ BMI-1 } & Forward & $\begin{array}{l}\text { 5'-TGGATCGGAAAGTAAACAAA } \\
\text { GAC-3' }\end{array}$ \\
\hline & Reverse & 5'-TGCATCACAGTCATTGCTGCT-3' \\
\hline \multirow[t]{2}{*}{ HAS 1} & Forward & 5'-TACAACCAGAAGTTCCTGGG-3' \\
\hline & Reverse & 5'-CTGGAGGTGTACTTGGTAGC-3' \\
\hline \multirow[t]{2}{*}{ HAS2 } & Forward & $\begin{array}{l}\text { 5'-GTGGATTATGTACAGGTTTG } \\
\text { TGA-3' }\end{array}$ \\
\hline & Reverse & 5'-TCCAACCATGGGATCTTCTT-3' \\
\hline \multirow[t]{2}{*}{ HAS3 } & Forward & $\begin{array}{l}\text { 5'-GAGATGTCCAGATCCTCAA } \\
\text { CAA-3' }\end{array}$ \\
\hline & Reverse & 5'-CCCACTAATACACTGCACAC-3' \\
\hline \multirow[t]{2}{*}{ Hyal-1 } & Forward & $\begin{array}{l}\text { 5'-CCAAGGAATCATGTCAGGCCAT } \\
\text { CAA-3' }\end{array}$ \\
\hline & Reverse & 5'-CCCACTGGTCACGTTCAGG-3' \\
\hline \multirow[t]{2}{*}{ Hyal-2 } & Forward & 5'-GGCTTAGTGAGATGGACCTC-3' \\
\hline & Reverse & 5'-CCGTGTCAGGTAATCTTTGAG-3' \\
\hline \multirow[t]{2}{*}{ CD44 } & Forward & GCTATTGAAAGCCTTGCAGAG \\
\hline & Reverse & CGCAGATCGATTTGAATATAACC \\
\hline \multirow[t]{2}{*}{ EGF } & Forward & AGTTTTTCTGAATGGGTCAAGG \\
\hline & Reverse & TCCAATTTATTGCCATTCCAG \\
\hline \multirow[t]{2}{*}{ EGFR } & Forward & ATGAGATGGAGGAAGACGG \\
\hline & Reverse & CGGCAGGATGTGGAGAT \\
\hline \multirow[t]{2}{*}{ Smad2 } & Forward & GGAGCAGAATACCGAAGGCA \\
\hline & Reverse & CTTGAGCAACGCACTGAAGG \\
\hline \multirow[t]{2}{*}{ Smad4 } & Forward & ATGACTTTGAGGGACAGC \\
\hline & Reverse & GGAAGCCACAGGAATG \\
\hline \multirow[t]{2}{*}{ P16 } & Forward & GGAGCAGCATGGAGCCTTC \\
\hline & Reverse & CATCATCATGACCTGGATC \\
\hline \multirow[t]{2}{*}{ MMP-1 } & Forward & TGTGGTGTCTCACAGCTTCC \\
\hline & Reverse & CTTGCCTCCCATCATTCTTC \\
\hline \multirow[t]{2}{*}{ GAPDH } & Forward & GTGAAGGTCGGAGTCAACG \\
\hline & Reverse & TGAGGTCAATGAAGGGGTC \\
\hline
\end{tabular}

EZH2, enhancer of zeste 2 polycomb repressive complex 2 subunit; BMI-1, B lymphoma Mo-MLV insertion region 1 homolog; HYAL, hyaluronidase; HAS, hyaluronan synthase; EGF, epidermal growth factor; EGFR, epidermal growth factor receptor; MMP-1, matrix metalloproteinase- 1 .

$2.5 \mathrm{~J} / \mathrm{cm}^{2}$ radiation group had no significant effect on senescence compared with the control $\left(0 \mathrm{~J} / \mathrm{cm}^{2}\right)$ group (Fig. 3B).

UVA radiation reduces hyaluronic acid (HA) content. A particle exclusion assay demonstrated that UVA radiation decreased HA content around HSF cells. Compared with the control group $\left(0 \mathrm{~J} / \mathrm{cm}^{2}\right)$, HSF cell exclusion to erythrocytes in the $10 \mathrm{~J} / \mathrm{cm}^{2}$ dose group decreased. The exclusion in the $0 \mathrm{~J} / \mathrm{cm}^{2}$ group disappeared after adding $100 \mu \mathrm{l}$ hyaluronidase $(1 \mathrm{mg} / \mathrm{ml})$, indicating that the exclusion effect of red blood cells was caused by

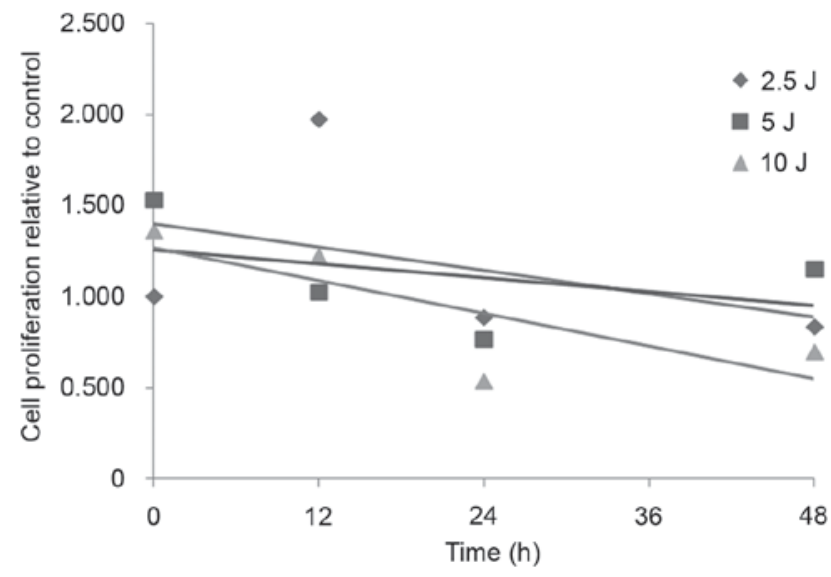

Figure 1. Effect of different doses of UVA radiation on fibroblast proliferation activity. Cultured human skin fibroblasts were treated with $0,2.5$, 5 or $10 \mathrm{~J} / \mathrm{cm}^{2}$ UVA irradiation, and incubated for $0,12,24$ and $48 \mathrm{~h}$. Data are presented as the mean \pm standard deviation of three separate experiments performed in triplicate, relative to the control group $\left(0 \mathrm{~J} / \mathrm{cm}^{2}\right)$. UVA, ultraviolet $\mathrm{A}$.

HA formation (Fig. 4). As skin aging is predominantly a result of extracellular matrix reduction, of which, HA is one of the most important components, the decline of hyaluronan content is a sign of skin aging (24). Notably, fibroblasts are the primary generators of HA (8). In the present experiment, UVA radiation was indicated to reduce the synthesis of HA in fibroblasts, which demonstrated that a photoaging cell model was successfully established.

High-dose UVA radiation increases mRNA expression levels of BMI-1 and EZH2. RT-qPCR results demonstrated that, $24 \mathrm{~h}$ after UVA radiation of HSF cells, BMI-1 and EZH2 mRNA expression levels in the $10 \mathrm{~J} / \mathrm{cm}^{2}$ dose group were significantly upregulated $(\mathrm{P}<0.05)$ compared with the control group $\left(0 \mathrm{~J} / \mathrm{cm}^{2} ;\right.$ Fig. 5$)$. However, the other dose groups demonstrated no significant differences compared with the control group. The $10 \mathrm{~J} / \mathrm{cm}^{2}$ dose therefore had the most significant effect on fibroblast proliferation, promoting apoptosis, inducing senescence, reducing the surrounding HA content and upregulating the mRNA expression levels of BMI-1 and EZH2. Based on these results, the $10 \mathrm{~J} / \mathrm{cm}^{2}$ dose was selected as the UVA treatment dose for the photoaging model.

GSK126 inhibits EZH2 mRNA expression. GSK126 is a methyl transferase activity inhibitor that could selectively inhibit EZH2-methyl transferase activity. In the present study, the results demonstrated that GSK126 also inhibited the mRNA expression of EZH2. GSK126 at a concentration of $2 \mu \mathrm{M}$ significantly inhibited $E Z H 2$ expression compared with the control group $(0 \mu \mathrm{M}$ GSK126) at 12 and $24 \mathrm{~h}(\mathrm{P}<0.05)$. The mRNA expression of the EZH2 was significantly downregulated after treatment of HSF cells for 12 and $24 \mathrm{~h}$ (P<0.05; Fig. 6). Therefore, $2 \mu \mathrm{M}$ GSK126 was selected as the inhibitor concentration for further analyses.

GSK126 inhibits photoaging in fibroblasts. GSK126 inhibited the photoaging of fibroblasts as well as expression of the key genes in the PcG family. After treating cells for $48 \mathrm{~h}$, cell growth state of the cells was observed under a microscope. 

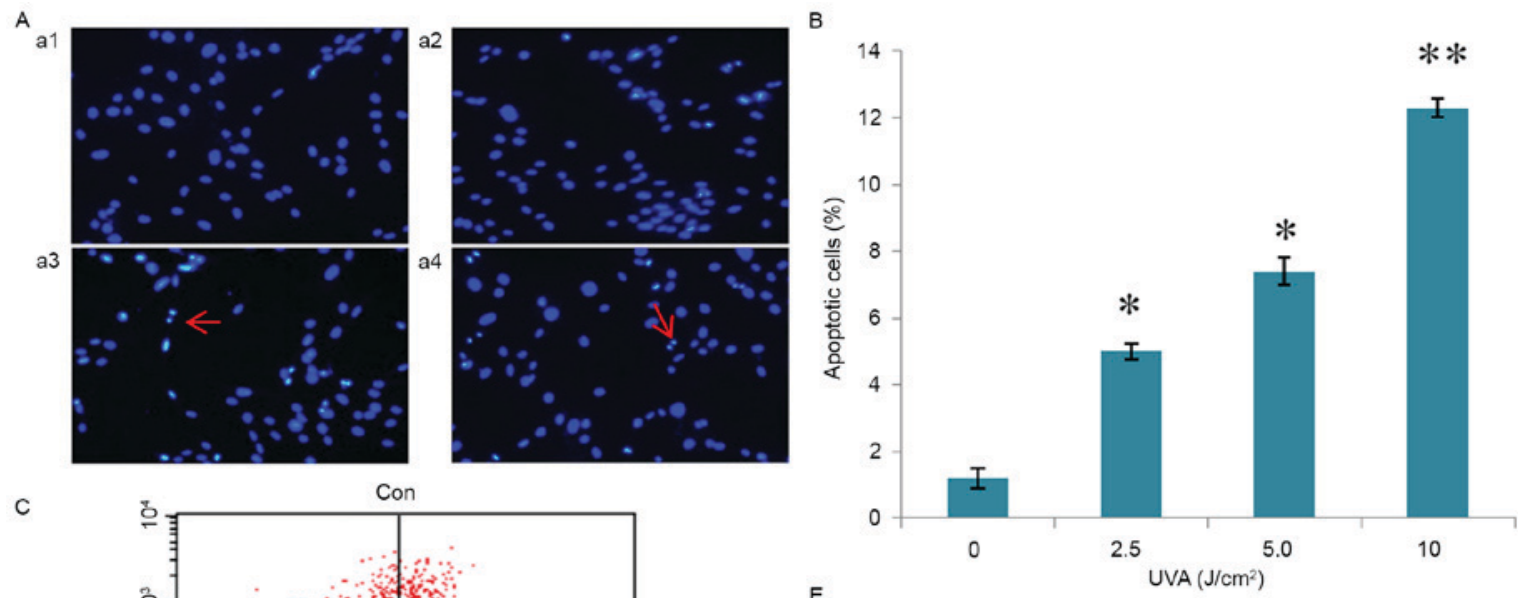

c

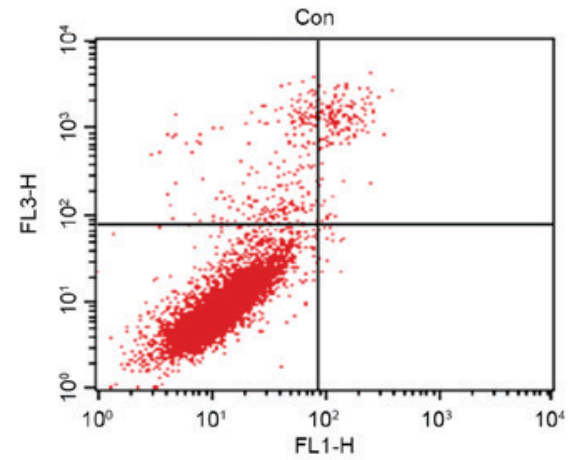

$E$
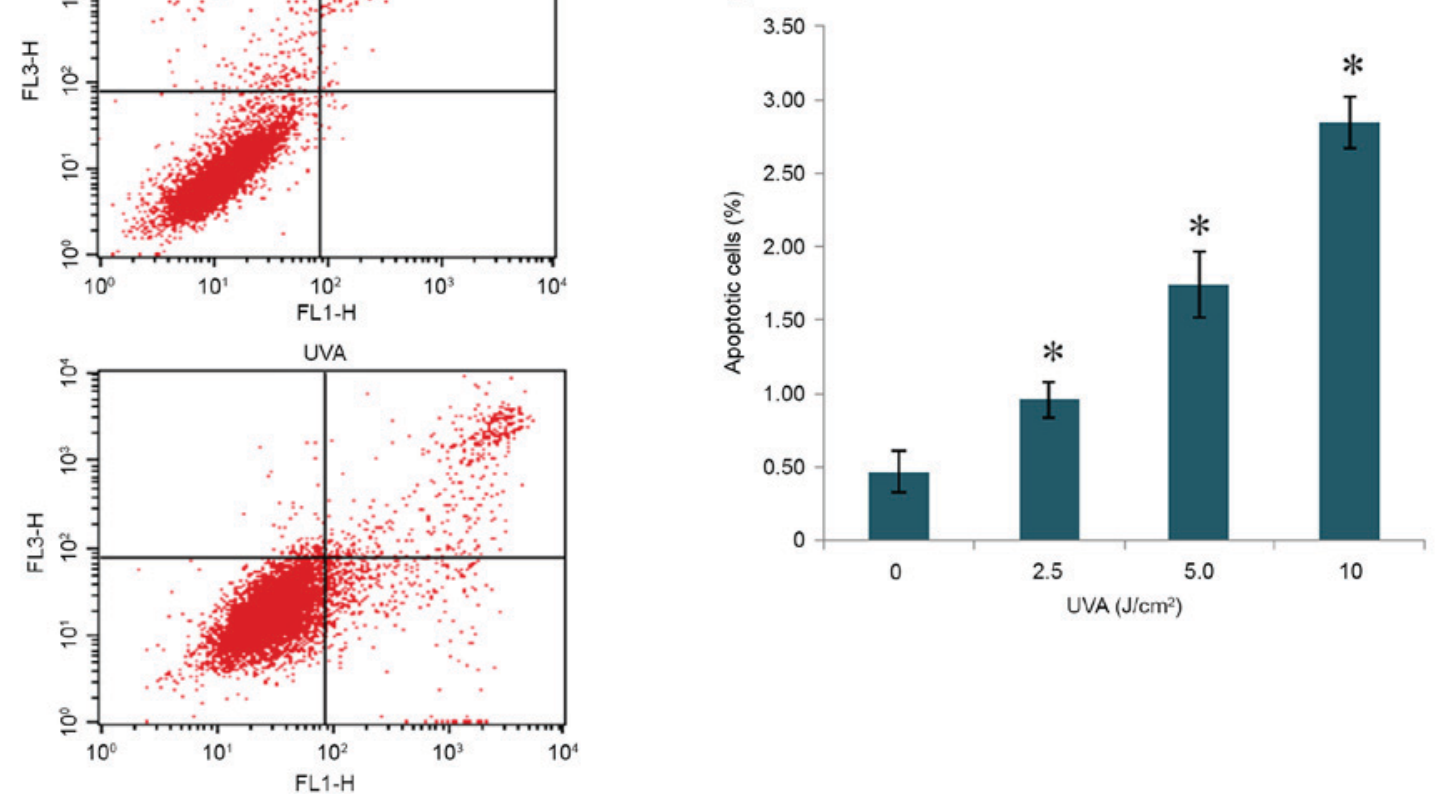

Figure 2. Effect of UVA radiation on fibroblast apoptosis. (A) Apoptosis in each radiation group was observed under a fluorescent microscope using Hoeschst apoptosis staining. Apoptotic nuclei demonstrated a dense white dye or crushed shape as indicated by the red arrows in a3 and a4. a1, $0 \mathrm{~J} / \mathrm{cm}^{2} \mathrm{group} ; \mathrm{a} 2$, $2.5 \mathrm{~J} / \mathrm{cm}^{2}$ group; a3, $5 \mathrm{~J} / \mathrm{cm}^{2}$ group; a4, $10 \mathrm{~J} / \mathrm{cm}^{2}$ group. Magnification, $\mathrm{x} 40$. (B) Number of apoptotic cells in each UVA radiation group. (C) Detection of apoptosis in the Con non-irradiated $\left(0 \mathrm{~J} / \mathrm{cm}^{2}\right)$ group by flow cytometry. The lower right quadrant of the non-irradiated group demonstrated a very small number of apoptotic cells. (D) Detection of apoptosis in the irradiated group. The lower-right quadrant of the irradiated group $\left(10 \mathrm{~J} / \mathrm{cm}^{2}\right)$ demonstrated an increase in the number of apoptotic cells compared with the Con group. (E) Statistical analysis of the flow cytometry results. Data are presented as the mean \pm standard deviation. ${ }^{* * *} \mathrm{P}<0.01$ and ${ }^{*} \mathrm{P}<0.05$ vs. the control group $\left(0 \mathrm{~J} / \mathrm{cm}^{2}\right)$. UVA, ultraviolet $\mathrm{A}$; Con, control.

A al

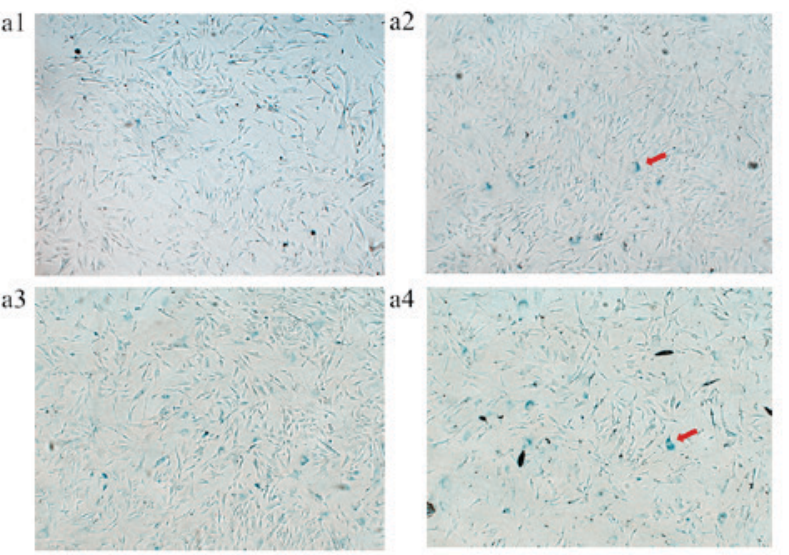

B

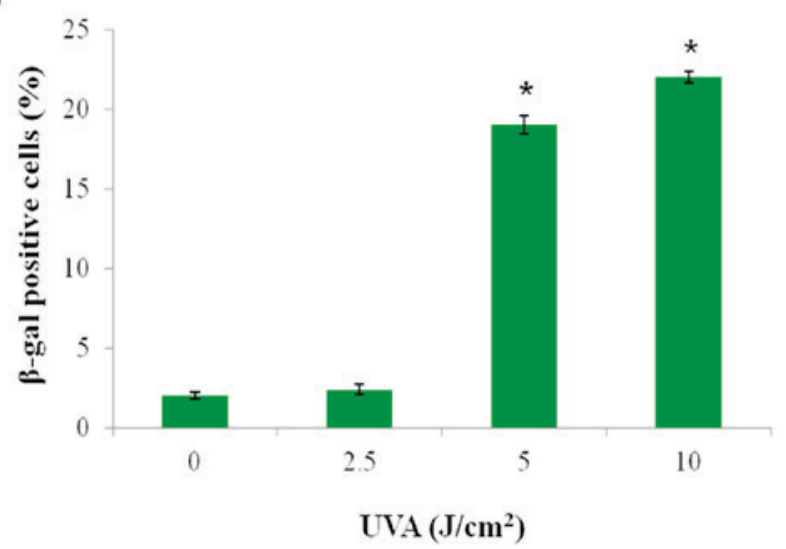

Figure 3. Effects of different doses of UVA radiation on aging of human skin fibroblasts. (A) Fibroblast senescence induced by different radiation doses. The dark blue precipitate indicates senescent cells indicated by the arrows in a2 and a4. a1, $0 \mathrm{~J} / \mathrm{cm}^{2} ; \mathrm{a} 2,2.5 \mathrm{~J} / \mathrm{cm}^{2} ; \mathrm{a} 3,5 \mathrm{~J} / \mathrm{cm}^{2} ; \mathrm{a} 4,10 \mathrm{~J} / \mathrm{cm}^{2}$. Magnification, $\mathrm{x} 40$. (B) UVA radiation-induced fibroblast senescence. The $\beta$-gal staining positive and negative cells in each group were counted statistically. Data are presented as the mean \pm standard deviation. "P $<0.05$ vs. the control group $\left(0 \mathrm{~J} / \mathrm{cm}^{2}\right)$. UVA, ultraviolet $\mathrm{A} ; \beta$-gal, $\beta$-galactosidase. 
A

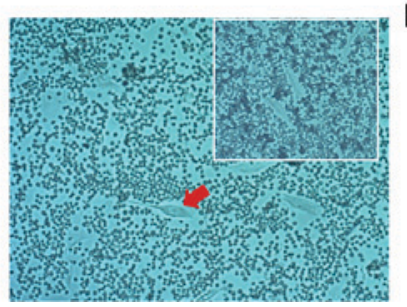

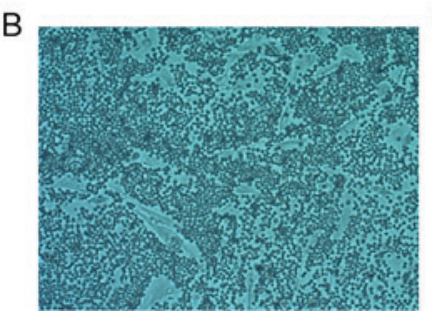

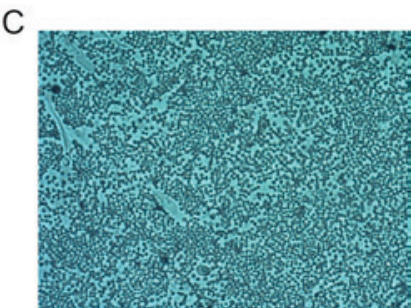

Figure 4. Effect of UVA radiation on the surrounding HA content of HSFs. The arrow indicates fibroblasts, surrounded by red blood cells. The formation of space around fibroblasts indicated the extent of fibroblast rejection of the surrounding erythrocytes and hyaluronan content around the $\mathrm{HSF}$ cells. (A) $0 \mathrm{~J} / \mathrm{cm}^{2}$; (B) $5 \mathrm{~J} / \mathrm{cm}^{2}$; (C) $10 \mathrm{~J} / \mathrm{cm}^{2}$ groups were indicated. Magnification, $\mathrm{x} 100$. The smaller box in (A) indicates the exclusion of erythrocytes around the fibroblasts following the addition of hyaluronidase. UVA, ultraviolet A; HA, hyaluronic acid; HSFs, human skin fibroblasts.
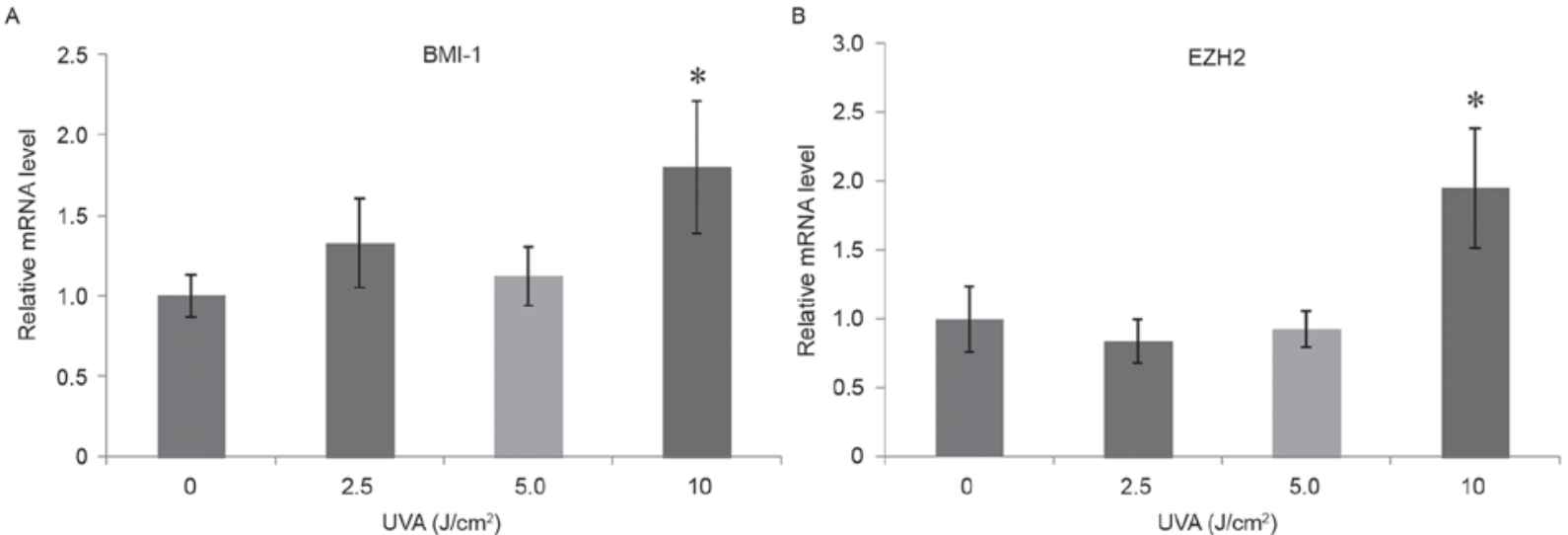

Figure 5. Effect of different doses of UVA radiation on the mRNA expression levels of (A) BMI-1 and (B) EZH2, key members of the polycomb group gene family. Data are presented as the mean \pm standard deviation. ${ }^{*} \mathrm{P}<0.05$ vs. the control group $\left(0 \mathrm{~J} / \mathrm{cm}^{2}\right)$. UVA, ultraviolet A; BMI-1, B lymphoma Mo-MLV insertion region 1 homolog; EZH2, enhancer of zeste 2 polycomb repressive complex 2 subunit.

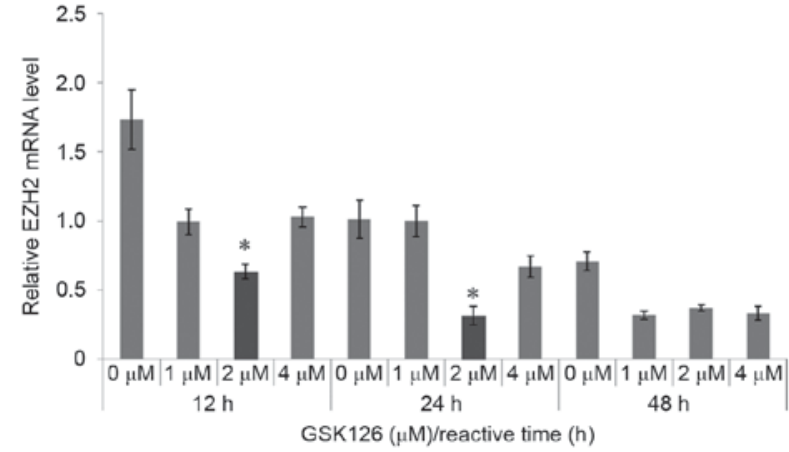

Figure 6. Effect of different concentrations of GSK126 on EZH2 mRNA expression levels. Data are presented as the mean \pm standard deviation. ${ }^{*} \mathrm{P}<0.05$ vs. the control group ( $0 \mu \mathrm{M}$ GSK126). EZH2, enhancer of zeste 2 polycomb repressive complex 2 subunit.

It was demonstrated that the addition of $2 \mu \mathrm{M}$ GSK126 did not significantly affect cell growth compared with the control group. However, a decrease in cell number, a poor growth state and UVA radiation-induced cellular senescence was observed in fibroblasts in the $10 \mathrm{~J} / \mathrm{cm}^{2}$ UVA irradiation group. Cell growth was largely unaffected in the UVA+GSK126 group, suggesting that inhibitors may resist UVA radiation-induced fibroblast senescence (Fig. 7A). RT-qPCR results demonstrated that the addition of GSK126 after UVA radiation significantly reduced the increase of EZH2 induced by UVA radiation
$(\mathrm{P}<0.05$; Fig. 7B). Following radiation, there was a significant increase in BMI-1 mRNA expression caused by the addition of GSK126 in the UVA+GSK126 group compared with the UVA radiation group $(\mathrm{P}<0.05$; Fig. $7 \mathrm{C})$. This may be closely linked to GSK126 resisting fibroblast senescence.

The effect of UVA radiation and GSK126 on HA anabolic family-related gene expression was analyzed. RT-qPCR analysis demonstrated that after $10 \mathrm{~J} / \mathrm{cm}^{2} \mathrm{UVA}$ radiation on HSF cells, HA synthase 1 (HAS1), HAS2, HAS3, CD44 and hyaluronidase (Hyal-1) were upregulated, with the highest expression observed for HAS1, compared with the control group without any treatment $(\mathrm{P}<0.05 ;$ Fig. 8A-E). After adding GSK126 inhibitors, the upregulation of HAS1 and Hyal-1 in the UVA group was significantly inhibited ( $\mathrm{P}<0.05$; Fig. 8A). However, HAS2, HAS3, CD44 in the UVA+GSK126 group were significantly upregulated $(\mathrm{P}<0.05$; Fig. 8B-E) compared with the UVA group, whereas Hyal-2 expression did not change significantly change (Fig. 8F).

Following this, the effect of UVA radiation and GSK126 on HSF cell photoaging molecular pathways was investigated (Fig. 9). RT-qPCR demonstrated that epidermal growth factor receptor (EGFR), smad2, smad4, P16 and matrix metalloproteinase-1 (MMP-1) mRNA expression levels were upregulated after $10 \mathrm{~J} / \mathrm{cm}^{2}$ UVA radiation on HSF cells. After the addition of GSK126, upregulation of smad2, smad4 and MMP-1 was significantly inhibited $(\mathrm{P}<0.05$; Fig. 9C, D and F). However, the upregulation of P16 gene expression was further promoted with 

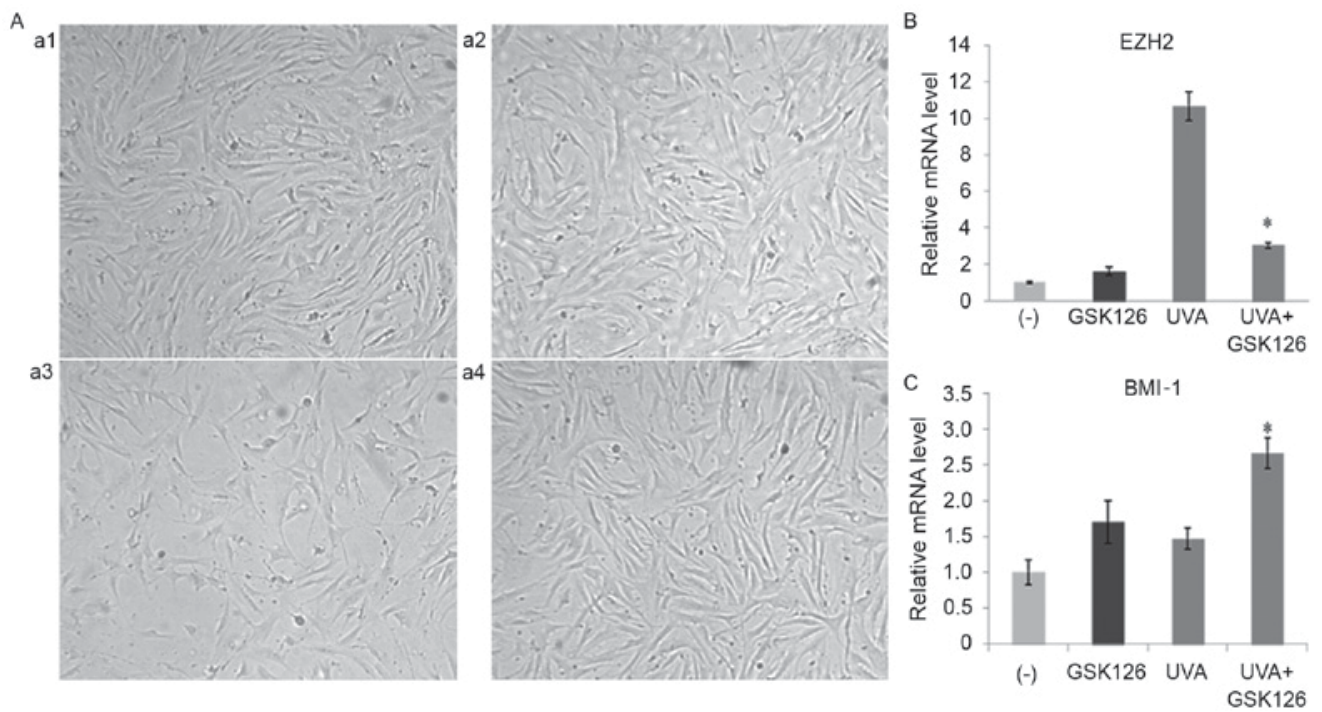

Figure 7. (A) Fibroblast growth after being treated with UVA radiation and GSK126 after 24 h. a1, (-); a2, GSK126 (2 $\mu$ M); a3, UVA (10 J/cm²); a4, UVA $\left(10 \mathrm{~J} / \mathrm{cm}^{2}\right)+\mathrm{GSK} 126(2 \mu \mathrm{M})$. Magnification, $\mathrm{x} 40$. (B) Effect of UVA radiation and GSK126 inhibitor on fibroblast mRNA expression levels of (B) EZH2 and (C) BMI-1. Data are presented as the mean \pm standard deviation. ${ }^{*} \mathrm{P}<0.05 \mathrm{vs.} \mathrm{UVA}\left(10 \mathrm{~J} / \mathrm{cm}^{2}\right)$. UVA, ultraviolet A; EZH2, enhancer of zeste 2 polycomb repressive complex 2 subunit; BMI-1, B lymphoma Mo-MLV insertion region 1 homolog; (-), control group without UVA and GSK126.

A

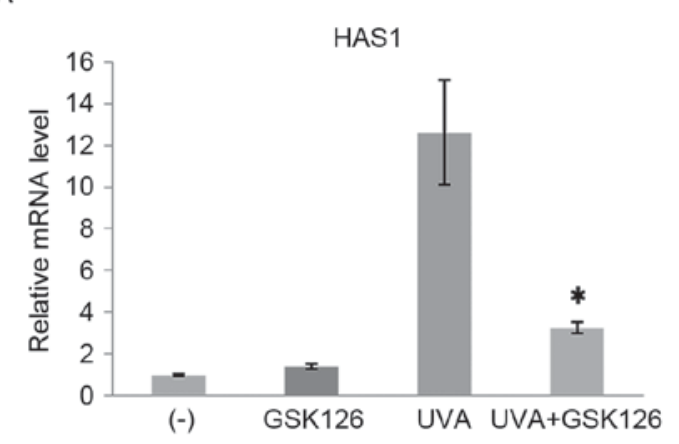

$\mathrm{C}$

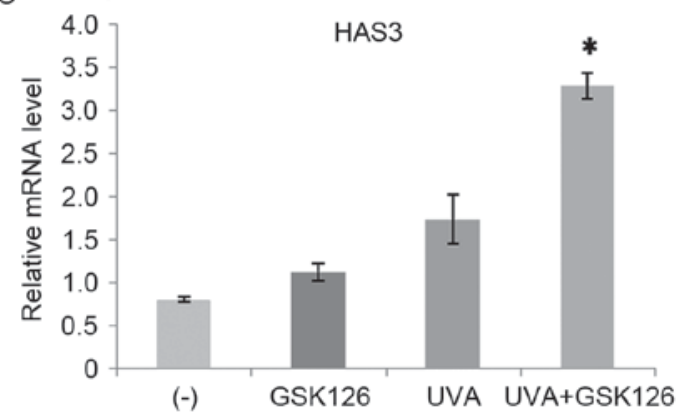

E

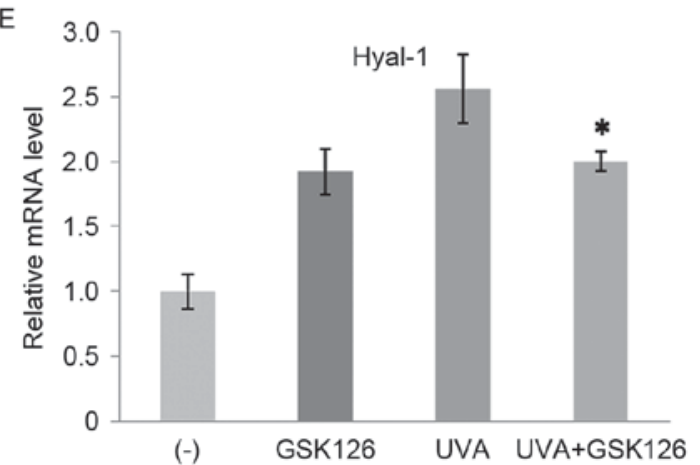

B

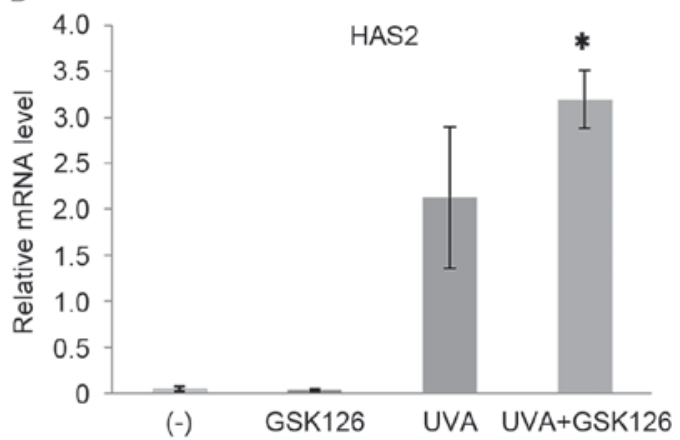

D

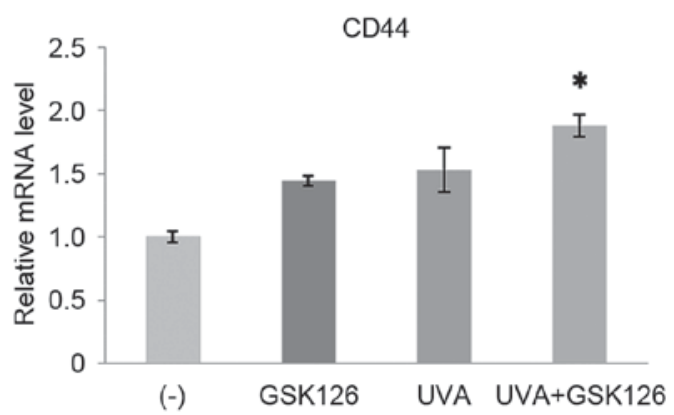

F

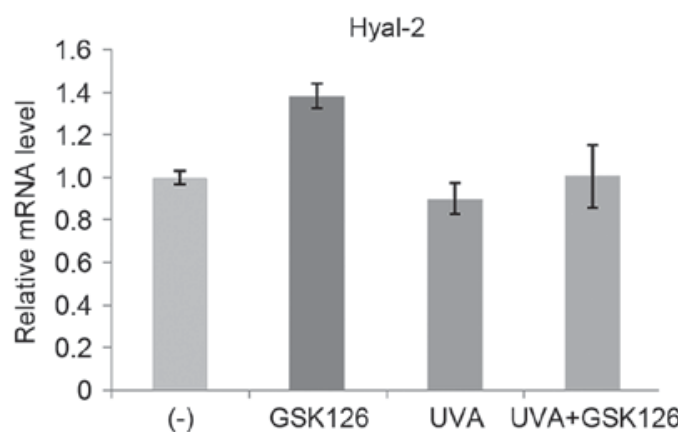

Figure 8. Effect of UVA radiation and GSK126 inhibitor on fibroblast mRNA expression levels of (A) HAS1, (B) HAS2, (C) HAS3, (D) CD44, (E) Hyal-1 and (F) Hyal-2. Data are presented as the mean \pm standard deviation. ${ }^{*} \mathrm{P}<0.05$ vs. UVA $\left(10 \mathrm{~J} / \mathrm{cm}^{2}\right)$. UVA, ultraviolet A; HAS, HA, hyaluronic acid synthase; $\mathrm{CD}$, cluster of differentiation; Hyal, hyaluronidase; (-), control group without any treatment. 

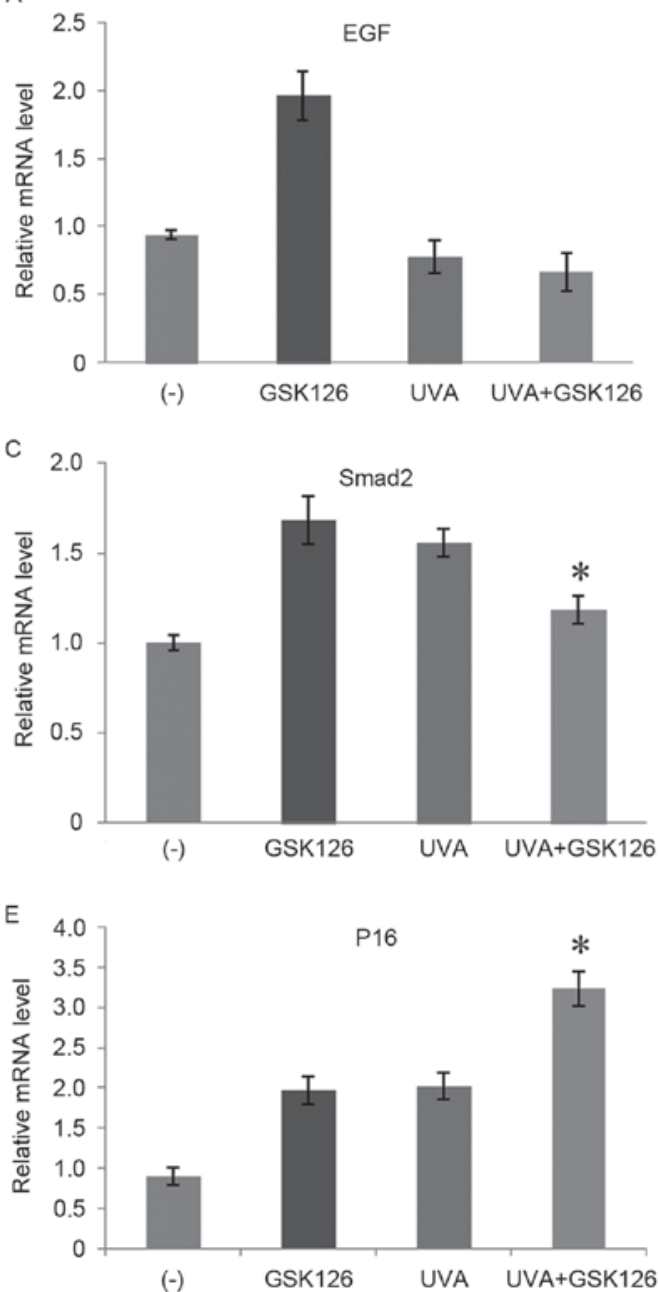
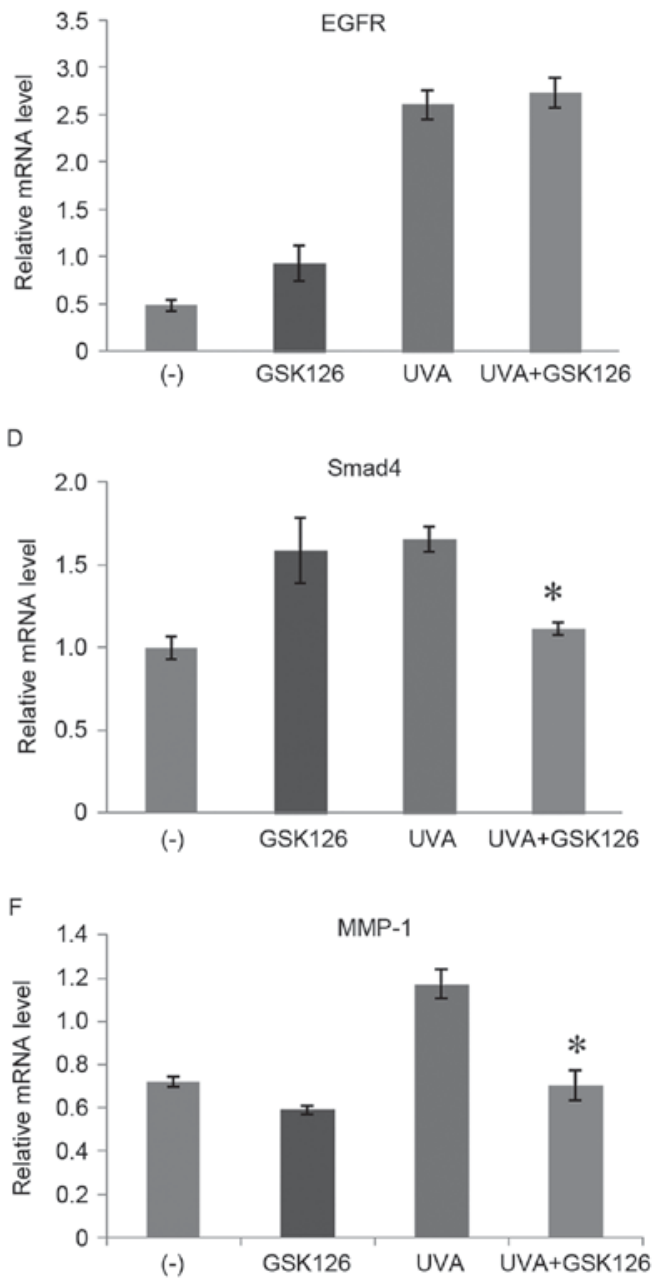

Figure 9. Effect of UVA radiation and GSK126 inhibitor on fibroblast mRNA expression levels of (A) EGF, (B) EGFR, (C) smad2, (D) smad4, (E) P16 and (F) MMP-1. Data are presented as the mean \pm standard deviation ${ }^{*} \mathrm{P}<0.05$ vs. UVA $\left(10 \mathrm{~J} / \mathrm{cm}^{2}\right)$. UVA, ultraviolet A; EGF, epidermal growth factor; EGFR, epidermal growth factor receptor; MMP, matrix metalloproteinase; (-), control group without any treatment.

the addition of GSK126 (P<0.05; Fig. 9E). Addition of GSK126 had no significant effect on epidermal growth factor (EGF) and EGFR expression after UVA radiation (Fig. 9A and B).

\section{Discussion}

Photoaging is the most common form of chronic sun-induced skin damage due to prolonged exposure. Dermal connective tissue changes induced by long-term UV irradiation lead to light skin damage and the appearance of aging (25). As the primary producers of the ECM scaffold, dermal fibroblasts are the basis of the occurrence of photoaging $(8,26,27)$. Due to its long wavelength, UVA may reach the skin up to the dermis, which is the main cause of photoaging (28). Therefore, the present study utilized HSF cells, and UVA radiation of fibroblasts was used to establish an in vitro aging model to observe the effect of UVA radiation and GSK126 on HSF cell senescence. It was demonstrated that HSF cell proliferation activity decreased, the percentage of apoptotic cells increased significantly, cell senescence increased and HA content around HSF cells decreased (i.e. the cell phenotype changed considerably) after UVA radiation on fibroblasts at a dose of $10 \mathrm{~J} / \mathrm{cm}^{2}$. Niu et al (29) and Lan et al (30) demonstrated that UVA radiation induced a significant decrease in fibroblast proliferation activity, which is consistent with the results of the present study.

In the study of the photoaging mechanism, it was previously demonstrated that UV radiation may lead to the apoptosis of a large number of dermal fibroblasts (light damage), and apoptosis promoted the development of photoaging $(9,31)$. Hoechst staining and flow cytometry methods were utilized in the present study to determine whether UVA radiation was able to induce fibroblast apoptosis, which was more obvious at higher radiation doses. This demonstrated that UVA radiation may cause direct fibroblast photodamage, resulting in fibroblast cell apoptosis; however, determination of the molecular mechanisms involved requires further investigation.

UVA radiation may reduce fibroblast HA synthesis and promote the occurrence of aging. An erythrocyte exclusion experiment was performed in the present study and it was determined that the particle size exclusion effect of red blood cells surrounding HSF cells decreased after UVA radiation. The size exclusion effect to red blood cells in the $10 \mathrm{~J} / \mathrm{cm}^{2}$ dose group almost disappeared, indicating that UVA radiation may lead to the decrease of HA content surrounding HSF cells.

The increase in $\beta$-gal activity levels within senescent cells is an indicator of cellular senescence (32,33). Fibroblast senescence 
is the basis of photoaging and UVA/UVB radiation are able to induce fibroblast senescence. A study by Wang et al (34) used $\beta$-gal staining after UVA irradiation of HSFs for $24 \mathrm{~h}$ and demonstrated that the percentage of senescent cells increased from $13.14 \pm 1.80$ to $56.72 \pm 2.04 \%$. In the present study, UVA radiation successfully induced fibroblast senescence. The results also demonstrated that UVA radiation induced a greater extent of HSF cell senescence at $10 \mathrm{~J} / \mathrm{cm}^{2}$ compared to lower doses.

In the present study, HSFs were subjected to UVA irradiation in order to induce apoptosis and senescence, thus decreasing cell proliferation. The most notable effect of UVA irradiation was observed at a dose of $10 \mathrm{~J} / \mathrm{cm}^{2}$. In addition, HA around the cells at this dose disappeared, and therefore it was concluded that $10 \mathrm{~J} / \mathrm{cm}^{2} \mathrm{UVA}$ radiation may successfully be applied to HSFs to establish an in vitro model of photoaging. It was also demonstrated that EZH2 and BMI-1 mRNA expression levels were upregulated significantly after $10 \mathrm{~J} / \mathrm{cm}^{2}$ of UVA radiation on HSF cells. Accordingly, it was speculated that the occurrence of HSF cell photoaging was closely related to the PcG family.

In the present study GSK126 was selected as the interfering factor of HSF photoaging, and it was demonstrated that fibroblasts restored growth after the addition of GSK126 following the UVA radiation-induced aging state. Furthermore, GSK126 significantly inhibited the upregulation of EZH2 mRNA expression induced by UVA radiation in photoaging HSF cells. It was suspected that the downregulation of EZH2 by GSK126 resulted in the decrease of $\mathrm{H} 3 \mathrm{~K} 9$ methylation levels and inhibited the formation of aging-associated heterochromatic loci $(20,35)$, thus preventing fibroblast senescence.

BMI-1 is a negative regulator of the inhibitor of Ink4a/Arf locus (36). The overexpression of BMI-1 in BMI-1 deficient primary mouse embryonic fibroblasts results in downregulation of P16 gene expression, as well as promotion of cell immortalization and anti-aging (37). As a negative regulator of the cell cycle, the increase in P16 is closely associated with cellular aging (36). The present study demonstrated that both BMI-1 and P16 expression after UVA radiation of HSF cells in the photoaging model increased, while GSK126 further promoted the expression of BMI-1 and P16. It was hypothesized that the simultaneous increase of BMI-1 and P16 interfered with the cell aging process. However, further studies are required to determine the exact mechanism.

Dermis HA has a vital role in strong hydrophilic interactions, keeping the skin moist and reducing the aging process $(38,39)$. The present study demonstrated that the expression of all three HAS and CD44 in the UVA radiation HSF cell photoaging model were upregulated, with HAS1 demonstrating the highest expression. GSK126 significantly reduced the upregulation of HAS1. The inhibitor also downregulated the expression of $\operatorname{smad} 2$ and smad4, whereas there was no significant difference in EGF and EGFR expression compared with UVA-treated cells. Based on these findings, it was hypothesized that GSK26 inhibits the CD44-EGFR- extracellular signal-regulated kinase (ERK) co-localization signal system by downregulating HAS1, smad 2 and smad4, thus inhibiting the differentiation of fibroblasts into myofibroblasts and impeding scar repair. The upregulation of HAS2, HAS3 and CD44 promoted the synthesis and secretion of HA, as well as the proliferation and migration of fibroblasts, However, HAS2, HAS3 and CD44 upregulation inhibited apoptosis and induced the regeneration and adhesion of keratinocytes (39). Furthermore, HAS2 upregulation may enhance the ability of HSF cells to block apoptosis. HAS3 upregulation has been demonstrated to promote the synthesis of a large number of small molecular weight HA, accelerate blood circulation and metabolism, and reduce the damage of reactive oxygen species and other substances to cells (10).

MMPs are a class of enzymes that cause the reduction of the ECM. The increased activity of MMPs may reduce the expression of type I collagen, which is one of the causes of skin aging $(40,41)$. The results of the present study demonstrated that MMP-1 gene expression was upregulated in UVA irradiated HSF cells in the photoaging model, indicating that the decomposition of collagen increased after UVA radiation. However, GSK126 significantly suppressed the upregulation of MMP-1 gene expression, thus reducing the degradation of collagen and resisting the effect of UVA radiation on fibroblast aging.

Sustained oxidative stress and the DNA damage response are closely related to cellular senescence (42). A previous study indicated that the nuclear factor (NF1)/smad4 transcriptional repressor protein complex was able to inhibit adenine nucleotide translocase 2 (ANT2) transcription-mediated oxidative shock and DNA damage response in aged fibroblasts (43). The results of the present study demonstrated that smad4 gene expression was upregulated in UVA irradiated HSF cells in the photoaging model. However, GSK126 significantly inhibited this effect, thereby reducing formation of the NF1/smad4 complex, promoting ANT2 transcription, reducing oxidative stress and the DNA damage response, and blocking the oxidative stress effects mediated by UVA radiation.

In conclusion, in the present study, PcG family control was closely related to UVA radiation-induced fibroblast photoaging. As a key gene, EZH2 had a vital role in the process of photoaging. GSK126 inhibited histone methylation catalytic activity and suppressed EZH2 gene expression. This inhibition may block UVA radiation-induced cell HSF aging through various mechanisms, such as reducing H3K9 methylation levels, inhibiting the formation of aging-associated heterochromatic loci, and interfering with cellular senescence by upregulating the expression of BMI-1 and P16 genes. Furthermore, GSK126 may differentially regulate the three kinds of HAS to inhibit the differentiation of fibroblasts into myofibroblasts, thus inhibiting scar repair, increasing the synthesis and secretion of HA, promoting the proliferation and migration of fibroblasts, accelerating blood circulation and metabolism and enhancing the ability of HSF cells against apoptosis. GSK1 also inhibited MMP-1 gene expression to reduce the degradation of collagen, inhibited Hyal-1 gene expression to reduce the degradation of HA, inhibited the expression of the smad4 gene to promote ANT2 transcription, reduced oxidative stress and DNA damage. However, the experimental study only measured gene expression. Therefore, analysis of the specific regulation modes and mechanisms of the PcG family is required for future studies.

\section{Acknowledgements}

The present study was supported by the National Natural Foundation of China (The Correlation Study between Chronic Delayed Wound Healing in Rats and Pseudomonas Aeruginosa Biofilm; grant no. 81372068). 


\section{Competing interests}

The authors declare that they have no competing interests.

\section{References}

1. Krutmann J, Bouloc A, Sore G, Bernard BA and Passeron T: The skin aging exposome. J Dermatol Sci 85: 152-161, 2017.

2. Peres PS, Terra VA, Guarnier FA, Cecchini R and Cecchini AL: Photoaging and chronological aging profile: Understanding oxidation of the skin. J Photochem Photobiol B 103: 93-97, 2011.

3. Li W, Zhou BR, Hua LJ, Guo Z and Luo D: Differential miRNA profile on photoaged primary human fibroblasts irradiated with ultraviolet A. Tumour Biol 34: 3491-500, 2013.

4. Gilchrest BA: Photoaging. J Invest Dermatol 133: E2-E6, 2013.

5. Lavker RM: Cutaneous aging: Chronologic versus photoaging. In Photodamage. Gilchrest B (ed). 1st edition. Wiley-Blackwell, Cambridge, MA, pp123-135,1995.

6. Helfrich YR, Sachs DL and Voorhees JJ: Overview of skin aging and photoaging. Dermatol Nurs 20: 177-184, 2008.

7. Thangapazham RL, Darling TN and Meyerle J: Alteration of skin properties with autologous dermal fibroblasts. Int J Mol Sci 15: 8407-8427, 2014.

8. Wong T, McGrath JA and Navsaria $\mathrm{H}$ : The role of fibroblasts in tissue engineering and regeneration. $\mathrm{Br} \mathrm{J}$ Dermatol 156: $1149-1155,2007$

9. Fisher GJ, Kang S, Varani J, Bata-Csorgo Z, Wan Y, Datta S and Voorhees JJ: Mechanisms of photoaging and chronological skin aging. Arch Dermatol 138: 1462-1470, 2002.

10. Wang Y, Lauer ME, Anand S, Mack JA and Maytin EV: Hyaluronan synthase 2 protects skin fibroblasts against apoptosis induced by environmental stress. J Biol Chem 289: 32253-32265, 2014.

11. Entwistle J, Hall CL and Turley EA: HA receptors: Regulators of signalling to the cytoskeleton. J Cell Biochem 61: 569-577, 1996.

12. Ghersetich I: Management of aging skin. J Eur Acad Dermatol Venereol 9: 51, 1997.

13. Chen T, Hou H, Fan Y, Wang S, Chen Q, Si L and Li B: Protective effect of gelatin peptides from pacific cod skin against photoaging by inhibiting the expression of MMPs via MAPK signaling pathway. J Photochem Photobiol B 165: 34-41, 2016.

14. Quan T, Qin Z, Xia W, Shao Y, Voorhees JJ and Fisher GJ Matrix-degrading metalloproteinases in photoaging. J Investig Dermatol Symp Proc 14: 20-24, 2009.

15. Hsu LY, Nien CY, Huang WM, Hsu SC and Chang TC: Synthesis and protective effects of bis $\{4$-[N,N-di-(carboxymethyl)amino] phenoxy alkane derivatives on UVA-induced production of MMP-1 in human skin fibroblasts. Chem Pharm Bull (Tokyo) 62 867-874, 2014.

16. Otte AP and Kwaks TH: Gene repression by polycomb group protein complexes: A distinct complex for every occasion? Curr Opin Genet Dev 13: 448-454, 2003.

17. Golbabapour S, Majid NA, Hassandarvish P, Hajrezaie M, Abdulla MA and Hadi AH: Gene silencing and Polycomb group proteins: An overview of their structure, mechanisms andphylogenetics. OMICS 17: 283-296, 2013.

18. Koubi M, Chabannon C and Duprez E: The biological complexity of Polycomb group proteins: The case of EZH2. Med Sci (Paris) 33: 499-505, 2017 (In French).

19. Gall Trošelj K, Novak Kujundzic R and Ugarkovic D: Polycomb repressive complex's evolutionary conserved function: The role of EZH2 status and cellular background. Clin Epigenetics 8: 55, 2016.

20. Narita M, Nũnez S, Heard E, Narita M, Lin AW, Hearn SA, Spector DL, Hannon GJ and Lowe SW: Rb-mediated matin formation and silencing of E2F target genes during cellular senescence. Cell 113: 703-716, 2003

21. Jacobs JL and van Lohuizen M: Polycomb repression: From cellular memory to cellular proliferation and cancer. Biochim Biophys Acta 1602: 151-161, 2002.

22. Bernert B, Porsch H and Heldin P: Hyaluronan synthase 2 (HAS2) promotes breast cancer cell invasion by suppression of tissue metalloproteinase inhibitor 1 (TIMP-1). J Biol Chem 286: 42349-42359, 2011.
23. Livak KJ and Schmittgen TD: Analysis of relative gene expression data using real-time quantitative PCR and the 2(-Delta Delta C(T)) method. Methods 25: 402-408, 2001

24. Nobile V, Buonocore D, Michelotti A and Marzatico F: Anti-aging and filling efficacy of six types hyaluronic acid based dermo-cosmetic treatment: Double blind, randomized clinical trial of efficacy and safety. J Cosmet Dermatol 13: 277-287, 2014

25. Kurban RS and Bhawan J: Histologic changes in skin associated with aging. J Dermatol Surg Oncol 16: 908-914, 1990.

26. Quan T, Wang F, Shao Y, Rittié L, Xia W, Orringer JS, Voorhees JJ and Fisher GJ: Enhancing structural support of the dermal microenvironment activates fibroblasts, endothelial cells and keratinocytes in aged human skin in vivo. J Invest Dermatol 133: 658-667, 2013.

27. Werner S, Krieg T and Smola H: Keratinocyte-fibroblast interactions in wound healing. J Invest Dermatol 127: 998-1008, 2007.

28. Philips N, Tuason M, Chang T, Lin Y, Tahir M and Rodriguez SG: Differential effects of ceramide on cell via-bility and extracellular matrix remodeling in keratinocytes and fibroblasts. Skin Pharmacol Physiol 22: 151-157, 2009.

29. Niu T, Tian Y, Cai Q, Ren Q and Wei L: Red light combined with blue light irradiation regulates proliferation and apoptosis in skin keratinocytes in combination with low concentrations of curcumin. PLoS One 10: e0138754, 2015.

30. Lan CC, Ho PY, Wu CS, Yang RC and Yu HS: LED $590 \mathrm{~nm}$ photomodulation reduces UVA-induced metalloproteinase-1 expression via upregulation of antioxidant enzyme catalase. J Dermatol Sci 78: 125-132, 2015.

31. Li DX, Deng TZ, Lv J and Ke J: Advanced glycation end products (AGEs) and their receptor (RAGE) induce apoptosis of periodontal ligament fibroblasts. Braz J Med Biol Res 47: 1036-1043, 2014.

32. Zhang JW, Zhang SS, Song JR, Sun K, Zong C, Zhao QD, Liu WT, Li R, Wu MC and Wei LX: Autophagy inhibition switches low-dose camptothecin-induced premature senescence to apoptosis in human colorectal cancer cells. Biochem Pharmacol 90: 265-275, 2014.

33. Yu A, Zheng Y, Zhang R, Huang J, Zhu Z, Zhou R, Jin D and Yang Z: Resistin impairs SIRT1 function and induces senescence-associated phenotype in hepatocytes. Mol Cell Endocrinol 377: 23-32, 2013.

34. Wang $\mathrm{YN}, \mathrm{Wu} \mathrm{W}$, Chen $\mathrm{HC}$ and Fang $\mathrm{H}$ : Genistein protects against UVB-induced senesc-ence-like characteristics in human dermal fibroblast by p66Shc down-regulation. J Dermatol Sci 58: 19-27, 2010

35. Aksoy O, Chicas A, Zeng T, Zhao Z, McCurrach M, Wang X and Lowe SW: The atypical E2F family member E2F7 couples the p53 and RB pathways during cellular senescence. Genes Dev 26: 1546-1557, 2012

36. Dhawan S, Tschen SI and Bhushan A: Bmi-1 regulates the Ink4a/Arf locus to control pancreatic beta-cell proliferation. Genes Dev 23: 906-911, 2009.

37. Jacobs JJ, Kieboom K, Marino S, DePinho RA and van Lohuizen M: The oncogene and Polycomb-group gene bmi-1 regulates cell proliferation and senescence through the ink4a locus. Nature 397: 164-168, 1999.

38. Lee BM, Han DG and Choi WS: Rejuvenating effects of facial Hydrofilling using Restylane vital. Arch Plast Surg 42: 282-287, 2015.

39. Simpson RM, Wells A, Thomas D, Stephens P, Steadman R and Phillips A: Aging fibroblasts resist phenotypic maturation because of impaired hyaluronan-dependent CD44/epidermal growth factor receptor signaling. Am J Pathol 176: 1215-1228, 2010.

40. Wang Y, Chen H, Wang W, Wang R, Liu ZL, Zhu W and Lian S: N-terminal5-merpeptideanalog P165 of amyloid precursor protein inhibits UVA-induced MMP-lexpression by suppressing the MAPK pathway in human dermal fibroblasts. Eur J Pharmacol 734: 1-8, 2014.

41. Chiang HM, Chen HC, Lin TJ, Shih IC and Wen KC: Michelia alba extract attenuates UVB-induced expression of matrix metalloproteinases via MAP kinase pathway in human dermal fibroblasts. Food Chem Toxicol 50: 4260-4269, 2012.

42. Hensley K and Floyd RA: Reactive oxygen species and protein oxidation in aging: A look back, a look ahead. Arch Biochem Biophys 397: 377-383, 2002.

43. Kretova M,Sabova L, Hodny Z, Bartek J,Kollarovic G, Nelson BD, Hubackova $S$ and Luciakova K: TGF- $\beta / N F 1 / S m a d 4-m e d i a t e d$ suppression of ANT2 contributes tooxidative stress in cellular senescence. Cell Signal 26: 2903-2911, 2014. 